\title{
KARAKTERISTIK MIE KERING TERBUAT DARI TEPUNG SUKUN (Artocarpus altilis) DAN PENAMBAHAN TELUR
}

Characteristics of Dry Noodles Made from Breadfruit Flour (Artocarpus altilis) and Egg

\author{
Utiya Listy Biyumna $^{1)}$, Wiwik Siti Windrati ${ }^{1)}$, Nurud Diniyah ${ }^{1) *}$ \\ ${ }^{1)}$ Jurusan Teknologi Hasil Pertanian Fakultas Teknologi Pertanian Universitas Jember \\ Jalan Kalimantan 37, Kampus Tegal Boto Jember 68121 \\ *E-mail: utiyalisty@gmail.com,nurud.ftp@unej.ac.id
}

\begin{abstract}
Dry noodle is dry food product that is usually made from wheat flour with food ingredients and food additives permitted. Breadfruit is a high carbohydrate of food as much as $78.9 \%$ if the breadfruit was bundled. High carbohydrate content in breadfruit flour can be used as a substitute food in noodle, but the protein content is low, it is necessary to add foods containing high protein, such as egg. The purpose of this research was to know the best influence and formulation on physical, sensorial and chemical characteristics of dry noodles substituted by breadfruit flour and egg. Design experimental in this research was used Completely Randomized Design (CRD) arranged as factorial with two factors, first factor (A) were ratio of wheat flour and breadfruit flour which include A1 (90\% of wheat flour and $10 \%$ of breadfruit flour), A2 ( $80 \%$ of wheat flour and $20 \%$ of breadfruit flour) and A3 (70\% of wheat flour and $30 \%$ of breadfruit flour, while the second factor $(B)$ was addition of egg include BI (5\% of egg), B2 (10\% of egg) and B3 (15\% of egg). The best treatment was dry noodle which made from $90 \%$ of wheat flour : $10 \%$ of breadfruit flour and 15\% of egg. The best characteristic of dry noodle has $11.72 \%$ protein content, moisture content $9.55 \%$, ash content $0,58 \%$, fat content $1.12 \%$, carbohydrate $77.04 \%$, lightness 62,58 , elasticity $26.60 \mathrm{~kg} / \mathrm{s}^{2}$, cooking loss $7.11 \%$, power rehydration 151,36\%; likes of color, smell, flavor, texture and overall favorite 4.3; 4.23; 4.37; 4.2; 4.4 (like-very like).
\end{abstract}

Keywords: dry noodle, substitution, breadfruit flour, egg

\section{PENDAHULUAN}

Mie kering adalah produk makanan kering yang dibuat dari tepung terigu dengan penambahan bahan makanan lain dan bahan tambahan makanan yang diizinkan, berbentuk khas mie (BSN, 1996) serta memiliki kadar air sebesar 810\%. Di Indonesia, mie telah menjadi pangan alternatif utama setelah nasi. Hal ini menyebabkan tingkat ketergantungan terhadap tepung terigu sangat tinggi, sehingga impor gandum terus meningkat. Padahal Indonesia bukan Negara penghasil gandum. Beberapa penelitian menggunakan bahan non terigu dalam pembuatan mie termasuk sorgum (Liu et al., 2012), pati jagung (Yuan et al., 2008; Yousif et al., 2012), kombinasi terigu- kecambah jagung-rumput laut (Jannah et al., 2014).

Indonesia memiliki potensi pangan lokal sumber karbohidrat yang belum dimanfaatkan secara optimal dan dapat mengurangi penggunaan tepung terigu, salah satunya sukun (Artocarpus altilis). Pemanfaatan sukun sebagai bahan baku industri pangan dapat ditingkatkan dengan cara penggunaan teknologi yang lebih modern yaitu diolah menjadi tepung sukun karena setelah dijadikan tepung, masa simpannya bertahan hingga 9 bulan (Purwanita, 2013).

Buah sukun memiliki kandungan karbohidrat yang cukup tinggi, yaitu 28,2 $\mathrm{g}$ tiap $100 \mathrm{~g}$ dan apabila ditepungkan, kandungan karbohidratnya meningkat 
menjadi 78,9 \% (FAO, 1972), sehingga dapat digunakan sebagai bahan substitusi pada pembuatan mie kering. Substitusi tepung sukun pada produk mie hanya berkisar antara 10-20\% karena bila lebih dari $20 \%$, produk mie berbasis tepung sukun akan mudah patah sewaktu dimasak karena tidak mengandung gluten (Widowati, 2003).

Tepung sukun memiliki kandungan pati yang lebih tinggi dibandingkan pada tepung terigu, yakni $\pm 76 \%$ pati pada tepung sukun, sedangkan pada tepung terigu yakni sebesar $\pm 70 \%$ (Utami, 1992). Kandungan pati dapat mempengaruhi tingkat gelatinisasi pati dan penyerapan air saat pengukusan mie kering. Tepung sukun mengandung protein yang cukup sedikit, yaitu sekitar 3,6 \% (Budijanto, 2009), sehingga akan mempengaruhi mie kering yang dihasilkan karena mie kering membutuhkan protein gluten.

Oleh karena itu, untuk mengatasi hal tersebut digunakan telur sebagai bahan tambahan karena telur memiliki kandungan protein yang cukup tinggi dan dapat digunakan sebagai stabilizer antara molekul pati tepung terigu dan tepung sukun. Pemakaian minimal telur adalah 3$10 \%$ dari berat tepung (Mulyadi et al., 2014). Penelitian ini bertujuan untuk mengetahui pengaruh dan kombinasi perlakuan terbaik antara rasio tepung terigu dan tepung sukun dengan penambahan telur, sehingga menghasilkan karakteristik mie kering dengan mutu yang baik dan disukai konsumen.

\section{METODE PENELITIAN}

\section{Alat dan Bahan}

Alat yang digunakan dalam penelitian ini terdiri atas alat-alat untuk pembuatan tepung sukun dan mie kering serta alat-alat untuk analisis. Peralatan untuk pembuatan tepung sukun dan mie kering meliputi peralatan utama yaitu blender (merk National), neraca analitik Ohaus Ap-310-O (Swiss), oven (Selecta), ekstruder, dan peralatan pendukung meliputi panci, kompor, sendok, piring, dandang, loyang, ayakan 80 mesh (Standard Sieve), pisau, baskom, tissue, lap. Alat yang digunakan untuk analisis yaitu eksikator, penjepit, colour reader Minolta CR 300 (Japan), penangas listrik, rheotex (Sun Scientific CO LTD), kurs porselin, kertas saring, beaker glass $100 \mathrm{ml}$ dan $150 \mathrm{ml}$, labu ukur $10 \mathrm{ml}$, soxhlet (DET-GRASS N), tabung reaksi, botol timbang, tanur (Noberthem model H3/P), stopwatch, erlenmeyer $250 \mathrm{ml}$, spatula besi dan labu kjeldahl (Buchi K-355).

Bahan utama penelitian yaitu buah sukun kuning yang diperoleh dari Pasar Tanjung, Jember, tepung terigu protein tinggi merk Cakra Kembar, telur ayam, garam, STPP dan air. Bahan untuk analisis yaitu aquadest, $\mathrm{H}_{2} \mathrm{SO}_{4}, \mathrm{Na}_{2} \mathrm{SO}_{4}-\mathrm{HgO}$, $\mathrm{NaOH}, \mathrm{HCl}$, petroleum benzen, asam borat dan methyl blue.

\section{Tahapan Penelitian}

\section{Pembuatan tepung sukun}

Buah sukun kuning tua dikupas dengan tujuan untuk memisahkan bagianbagian yang tidak dipakai yaitu bagian kulit, tangkai dan bonggol (hati) buah. Kemudian dicuci bersih dengan air mengalir untuk mengurangi pencoklatan (browning) pada bahan. Setelah itu, dilakukan proses pengecilan ukuran yaitu pemotongan tipis-tipis seperti chip untuk mempercepat proses pengeringan. Lalu dilakukan perendaman menggunakan air bersih selama 30-60 menit untuk mengurangi pencoklatan (browning) pada bahan, setelah itu ditiriskan dan didiamkan selama \pm 5 menit untuk mengurangi air pada chip. Chip sukun dikeringkan menggunakan oven selama 24 jam pada suhu $55-60^{\circ} \mathrm{C}$. Kemudian didiamkan (dikering anginkan) dan dilakukan penggilingan menggunakan blender yang bertujuan untuk memperkecil ukuran bahan menjadi tepung. Selanjutnya diayak menggunakan ayakan 80 mesh untuk 
menyeragamkan ukuran butiran tepung sukun.

\section{Pembuatan mie kering}

Tepung sukun pada pembuatan mie kering ditambahkan dengan variasi jumlah yaitu $10 \%, 20 \%$ dan $30 \%$. Tepung terigu yang digunakan yaitu dengan variasi jumlah 90\%, 80\% dan 70\%. Bahan tambahan telur yang digunakan yaitu sebesar 5, 10 dan 15\%. Sebagai kontrol, tepung terigu yang digunakan yaitu $100 \%$ dengan penambahan telur sebanyak 5\%, tanpa substitusi tepung sukun. Beberapa bahan tambahan lain yang juga digunakan yaitu garam $2 \%$, STPP $0,3 \%$ dan air $35 \%$. Langkah selanjutnya yaitu mencampurkan bahan-bahan ke dalam baskom, lalu dimasukkan ke dalam ekstruder. Bahan masuk ke dalam ekstruder, tombol mix ditekan untuk mencampur semua bahan hingga merata dan homogen, kemudian diatur waktu pencampuran selama \pm 3 menit. Selanjutnya, tombol extrude ditekan yang telah diatur waktunya selama \pm 7 menit sampai adonan mie keluar dari ekstruder. Ketika mie keluar dari ekstruder, mie dipotong-potong menggunakan pisau dengan panjang \pm 7 $\mathrm{cm}$. Agar tidak lengket, potonganpotongan mie yang telah terbentuk ditaburi dengan sedikit tepung gandum. Potonganpotongan mie selanjutnya dikukus selama 10-15 menit, kemudian diangkat, diletakkan di atas loyang bersih dan didiamkan selama \pm 3 menit untuk mengurangi kandungan air pada mie. Kemudian dikeringkan menggunakan oven pada suhu $45-50^{\circ} \mathrm{C}$ selama \pm 18 jam.

\section{Rancangan Percobaan}

Penelitian dilakukan dengan menggunakan Rancangan Acak Lengkap (RAL) yang disusun secara faktorial dengan dua faktor dan diulang sebanyak tiga kali dengan satu kontrol. Faktor pertama (A) yaitu rasio penggunaan tepung terigu dan tepung sukun yang meliputi A1 (90\% tepung terigu dan $10 \%$ tepung sukun), A2 (80\% tepung terigu dan $20 \%$ tepung sukun) dan A3 (70\% tepung terigu dan $30 \%$ tepung sukun. Faktor kedua (B) yaitu tingkat penambahan telur meliputi B1 (telur 5\% (b/v)), B2 (telur $10 \%(\mathrm{~b} / \mathrm{v})$ ) dan B3 (telur 15\% (b/v)). Kombinasi perlakuan dari kedua faktor dapat dilihat pada Tabel 1.

Tabel 1. Kombinasi perlakuan mie kering

\begin{tabular}{cccc}
\hline A/B & A1 & A2 & A3 \\
\hline B1 & A1B1 & A2B1 & A3B1 \\
B2 & A1B2 & A2B2 & A3B2 \\
B3 & A1B3 & A2B3 & A3B3 \\
\hline
\end{tabular}

\section{Metode Analisis}

Analisis dilakukan pada mie kering. Analisis yang dilakukan meliputi uji fisik dan sensoris pada seluruh formula mie kering. Uji fisik yang diamati yaitu kecerahan warna (Manual Book Colour), daya rehidrasi (Romlah dan Haryadi, 1997), elastisitas dan cooking loss (AACC, 2000). Uji sensoris diamati dengan uji kesukaan meliputi warna, aroma, rasa, elastisitas dan kesukaan keseluruhan (Meilgaard et al., 2000). Selanjutnya, penentuan perlakuan terbaik dari hasil analisis fisik dan sensoris dengan menggunakan uji efektivitas (De Garmo et $a l .$, 1984). Hasil dari perlakuan terbaik dan kontrol dilakukan uji kimia meliputi analisis kadar air, analisis kadar abu, analisis kadar protein, analisis kadar lemak menggunakan (AACC, 2000) dan analisis karbohidrat (Sudarmadji et al., 1997).

Setiap formulasi dilakukan pengamatan sensoris dan fisik, kemudian dua produk mie kering terbaik (dilakukan dengan uji efektivitas) dan satu perlakuan kontrol dilakukan pengamatan secara kimia. Data hasil pengamatan ditampilkan dalam bentuk grafik batang. Data analisis dari uji sensoris dan fisik dianalisis menggunakan analisis sidik ragam (ANOVA) pada taraf 5\% dan jika terdapat perbedaan dilanjutkan uji beda dengan menggunakan DNMRT (Duncan New Multiple Range Test) menggunakan Ms. 
Excel. Data hasil analisis kimia, diolah menggunakan analisis perbedaan T-test menggunakan aplikasi minitab 17.

Daya rehidrasi (Romlah dan Haryadi, 1997)

Pengukuran daya rehidrasi dilakukan dengan metode penimbangan. Daya rehidrasi adalah kemampuan mie untuk menyerap air setelah gelatinisasi. Pengukuran dilakukan dengan menimbang 5 g mie mentah sebagai a g, kemudian direbus sampai tergelatinisasi sempurna ( \pm 4 menit). Setelah masak, kemudian ditiriskan dan ditimbang sebagai $\mathrm{b} g$.

Daya rehidrasi $(\%)=((b-a) / a) \times 100 \%$

\section{Elastisitas}

Pengukuran elastisitas dilakukan dengan menggunakan metode perhitungan tingkat kemuluran mie akibat diberi tekanan atau beban. Mie direbus sampai masak \pm 7 menit, kemudian seuntai mie dengan panjang $\pm 4 \mathrm{~cm}$ diletakkan di atas gabus yang di tengah gabus tersebut telah dilubangi dengan panjang $\pm 2 \mathrm{~cm}$ dan diameter $\pm 2 \mathrm{~cm}$, kedua ujung mie ditusuk dengan jarum. Adapun cara pengukuran elastisitas menggunakan rheotex yaitu dengan menyiapkan dan mengatur skala pada titik nol, kemudian sampel mie yang berada di atas gabus diletakkan pada meja objek yang tersedia pada alat rheotex. Tombol start ditekan dan tunggu hingga jarum rheotex menusuk sampel mie hingga terputus. Setelah itu, skala yang tertera dalam satuan gram dicatat sebagai nilai hitung. Catat panjang dan beban yang tertera pada rheotex. Perhitungan nilai elastisitas dilakukan berdasarkan gaya pegas, yaitu:

$\mathrm{k}=$ elastisitas

$$
\begin{aligned}
& \mathrm{F} \quad=\mathrm{k} \cdot \mathrm{x} \\
& \mathrm{m} \cdot \mathrm{g}=\mathrm{k} \cdot \mathrm{x} \\
& \mathrm{k}=(\mathrm{m} \cdot \mathrm{g}) / \mathrm{x}
\end{aligned}
$$

$\mathrm{x}=$ panjang yang tertera pada rheotex $(\mathrm{m})$

$\mathrm{m}=$ berat yang tertera pada rheotex $(\mathrm{kg})$

$\mathrm{g}=$ konstanta gravitasi bumi $\left(9,8 \mathrm{~m} / \mathrm{s}^{2}\right)$

\section{Cooking loss}

Pengukuran cooking loss dapat dilakukan dengan cara menimbang 5 gram sampel mentah. Lalu menimbang beaker glass $100 \mathrm{ml}$ kosong (a gram) dan diisi dengan air lalu dididihkan. Sampel direbus \pm 7 menit, ditiriskan hingga tidak ada air yang menetes lagi, sisa air rebusan dipanaskan kembali hingga tersisa setengah bagian (filtrat). Filtrat selanjutnya dioven selama 24 jam dan ditimbang beratnya hingga konstan (b gram) Perhitungannya dapat diukur seperti persamaan berikut:

$$
\text { Cooking loss }(\%)=[(\mathrm{b}-\mathrm{a}) / 5)] \times 100 \%
$$

\section{Uji sensoris (Meilgaard et al., 2000)}

Pengujian sensoris dilakukan dengan uji kesukaan. Uji kesukaan dilakukan untuk mengetahui tingkat penerimaan konsumen terhadap mie kering yang dihasilkan meliputi warna, aroma, rasa, tekstur dan kesukaan keseluruhan. Pengujian dilakukan dengan memberikan 10 sampel mie (9 mie perlakuan dan satu sebagai kontrol) kepada panelis. Sebelumnya, sampel diberi kode dengan 3 digit angka secara acak untuk menghindari terjadinya bias. Jumlah panelis minimal untuk uji kesukaan adalah 30 orang dengan skala numerik 1 (tidak suka) sampai 5 (sangat suka).

\section{HASIL DAN PEMBAHASAN}

\section{Sifat Fisik}

\section{Kecerahan warna}

Hasil analisis sidik ragam pada taraf uji ( $\alpha$ ) 5\% menunjukkan bahwa mie kering yang terbuat dari substitusi tepung sukun dan telur berpengaruh nyata terhadap nilai kecerahan mie kering yang dihasilkan. Semakin rendah substitusi tepung sukun dan semakin banyak penambahan telur, warna yang dihasilkan semakin cerah. Tepung sukun memiliki warna yang lebih gelap (putih kekuningan) dibandingkan tepung terigu (putih), sehingga semakin banyak tepung sukun yang digunakan, mie 
kering yang dihasilkan semakin gelap (putih kekuningan). Tepung terigu memiliki nilai kecerahan warna 74,97 , sedangkan tepung sukun memiliki kecerahan warna 69,19 (Khusna, 2016).

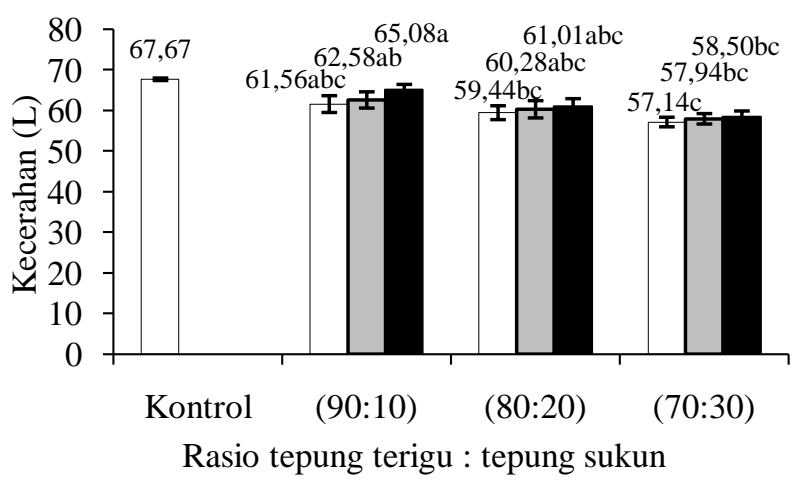

Gambar 1. Nilai kecerahan warna mie kering dengan substitusi tepung sukun dan penambahan telur $\square=5 \%, \square=10 \%$ dan $\boldsymbol{\square}=15 \%$

Warna yang lebih gelap (putih kekuningan) pada tepung sukun dikarenakan adanya reaksi browning enzimatis antara enzim polifenol oksidase yang berkontak langsung dengan oksigen di udara saat pengupasan dan pendiaman sukun. Selain itu, adanya reaksi maillard yang terjadi akibat adanya reaksi antara gula reduksi dari karbohidrat dengan gugus amina primer dari protein saat proses pengukusan mie kering. Penambahan telur dapat meningkatkan kecerahan warna mie kering karena adanya kuning telur sehingga dapat mencerahkan warna mie kering.

\section{Daya rehidrasi}

Hasil analisis sidik ragam pada taraf uji ( $\alpha$ ) 5\% menunjukkan bahwa mie kering yang terbuat dari substitusi tepung sukun dan telur berpengaruh nyata terhadap daya rehidrasi mie kering yang dihasilkan. Semakin tinggi substitusi tepung sukun dan penambahan telur, daya rehidrasi mie kering yang dihasilkan semakin meningkat.



Gambar 2. Nilai daya rehidrasi mie kering dengan substitusi tepung sukun dan penambahan $\square=5 \%$ telur, $\square=10 \%$ telur dan $\boldsymbol{\square}=15 \%$ telur

Tepung sukun memiliki karbohidrat lebih banyak yakni 78,90\% dibandingkan tepung terigu yakni $77,30 \%$ (Direktorat Gizi Depkes RI, 2010). Di dalam karbohidrat terdapat kandungan pati. Tepung terigu mengandung pati $\pm 70 \%$, yang terbagi atas fraksi amilosa 19-26\% dan amilopektin 74-81\% (Puspanti, 2005), sedangkan tepung terigu mengandung $76 \%$ pati, yang terbagi atas fraksi amilosa $18 \%$ dan $82 \%$ amilopektin. Semakin tinggi kadar pati pada bahan, maka akan mempercepat terjadinya gelatinisasi pati dan penyerapan air. Daya rehidrasi meningkat dengan semakin banyaknya gugus hidroksil pada pati. Penambahan telur juga dapat meningkatkan daya rehidrasi mie kering karena telur memiliki kandungan protein yang tinggi yang bersifat mengikat air, sehingga dapat meningkatkan daya serap air mie kering.

\section{Elastisitas}

Hasil analisis sidik ragam pada taraf uji ( $\alpha$ ) 5\% menunjukkan bahwa mie kering yang terbuat dari substitusi tepung sukun dan telur berpengaruh tidak nyata terhadap elastisitas mie kering yang dihasilkan. Semakin rendah substitusi tepung sukun dan semakin tinggi penambahan telur, elastisitas mie kering semakin meningkat. 
Tepung sukun tidak memiliki gluten, sehingga mie kering dengan substitusi tepung sukun yang semakin banyak, kandungan protein gluten semakin menurun. Gluten terbentuk dari glutenin yang berperan sebagai pembentuk sifat elastis dapat membuat ikatan antar granula pati lebih rapat, sehingga gel pati lebih kuat dan tahan terhadap tarikan (Nurcahyo et al., 2014).

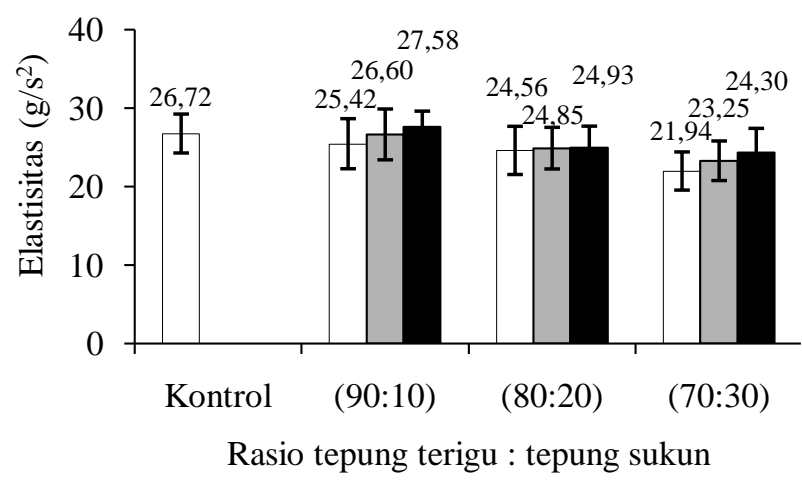

Gambar 3. Nilai elastisitas mie kering dengan substitusi tepung sukun dan penambahan $\square=5 \%$ telur, $\square=10 \%$ telur, $\mathbf{\square}=15 \%$ telur

Penambahan telur dapat meningkatkan daya elastisitas mie kering karena putih telur dapat membentuk lapisan yang kuat atau daya rekat yang bagus, sehingga dapat memperbaiki tekstur mie. Lesitin dalam kuning telur berfungsi sebagai pengemulsi, sehingga dapat membantu pembentukan tekstur mie.

\section{Cooking loss}

Hasil analisis sidik ragam pada taraf uji $(\alpha)$ 5\% menunjukkan bahwa mie kering yang terbuat dari substitusi tepung sukun dan telur berpengaruh nyata terhadap cooking loss mie kering yang dihasilkan. Semakin tinggi substitusi tepung sukun dan semakin rendah penambahan telur, cooking loss mie kering semakin meningkat.

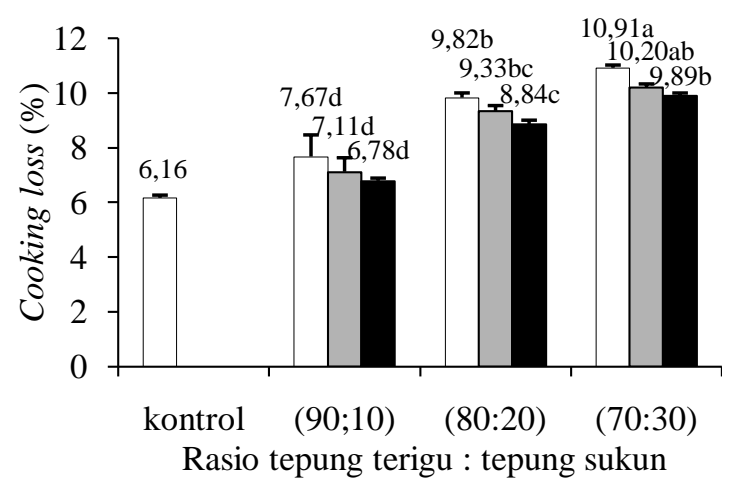

Gambar 4. Nilai cooking loss mie kering dengan substitusi tepung sukun dan penambahan $\square=5 \%$ telur, $\square=10 \%$ telur dan $\mathbf{\square}=15 \%$ telur

Semakin tinggi substitusi tepung sukun, cooking loss mie kering semakin meningkat karena kandungan gluten pada mie kering yang semakin berkurang. Tepung sukun tidak memiliki kandungan gluten. Apabila kandungan gluten pada mie kering berkurang, maka banyak partikel-partikel bahan yang terlepas, sehingga semakin banyak padatan yang hilang bersama air selama proses pemasakan dan menyebabkan struktur keseluruhan mie melemah (Rayas-Duarte, 1996).

Penambahan telur yang semakin tinggi dapat menurunkan cooking loss mie kering karena telur memiliki kandungan protein yang tinggi dan bersifat emulsifier yang bersifat mengikat air. Selain sebagai pengemulsi, lesitin dalam kuning telur juga dapat mempercepat hidrasi air pada tepung. Telur dapat menambah kualitas gluten pada mie kering.

\section{Sifat Sensoris}

\section{Kesukaan warna}

Hasil uji hedonik (uji kesukaan) warna mie kering dengan substitusi tepung sukun dan penambahan telur berkisar antara 3,43 - 4,1 (agak suka sampai suka). Hasil sidik ragam warna mie kering dengan taraf uji 5\% menunjukkan bahwa rasio tepung terigu dan tepung sukun dengan penambahan telur berpengaruh nyata terhadap kesukaan warna panelis. 


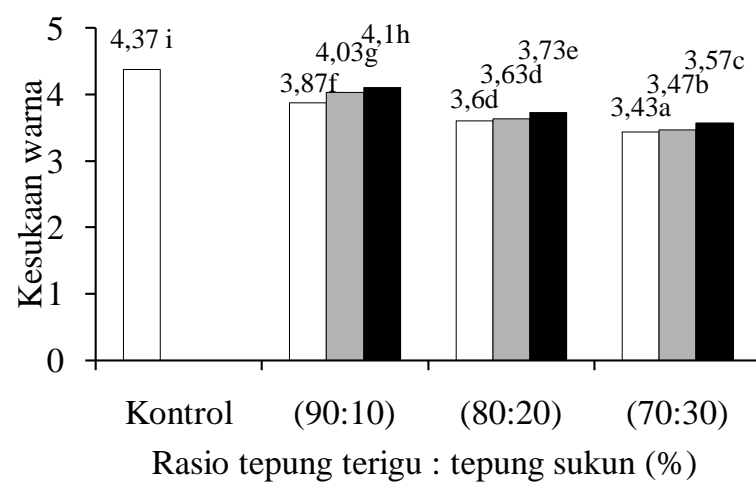

Gambar 5. Nilai kesukaan warna mie kering dengan substitusi tepung sukun dan penambahan $\square=5 \%$ telur, $\square=10 \%$ telur dan $\mathbf{\square}=15 \%$ telur

Nilai kesukaan panelis terhadap mie kering semakin menurun seiring dengan peningkatan konsentrasi substitusi tepung sukun karena semakin tinggi konsentrasi substitusi tepung sukun, warna mie kering yang dihasilkan lebih gelap, sehingga tidak disukai oleh konsumen.

Penambahan telur dapat meningkatkan warna mie kering. Umumnya panelis lebih menyukai mie kering yang berwarna kuning. Menurut Setianingrum dan Marsono (1999), mie yang disukai masyarakat Indonesia adalah mie dengan warna kuning dengan bentuk yang khas berupa pilinan panjang yang dapat mengembang sampai batas tertentu dan kalau direbus tidak banyak padatan yang hilang.

\section{Kesukaan aroma}

Hasil uji hedonik (uji kesukaan) aroma mie kering dengan substitusi tepung sukun dan penambahan telur berkisar antara 3,4 - 4,23 (agak suka sampai suka). Hasil sidik ragam aroma mie kering dengan taraf uji 5\% menunjukkan bahwa rasio tepung terigu dan tepung sukun dengan penambahan telur berpengaruh nyata terhadap kesukaan aroma panelis.

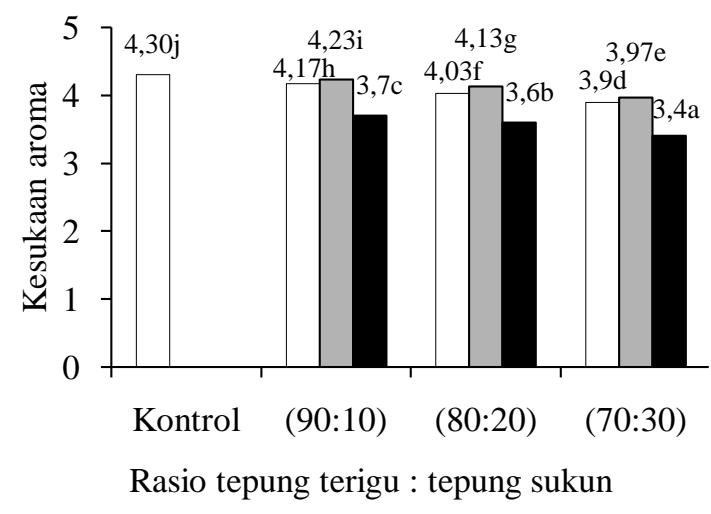

Gambar 6. Nilai kesukaan aroma mie kering dengan substitusi tepung sukun dan penambahan telur: $\square=5 \%, \square=10 \%$ dan $\boldsymbol{\nabla}=15 \%$

Nilai penerimaan panelis terhadap aroma mie kering semakin menurun seiring dengan peningkatan konsentrasi substitusi tepung sukun karena aroma khas buah sukun pada mie kering lebih terasa, sehingga menurunkan tingkat kesukaan panelis terhadap aroma mie kering yang dihasilkan. Penambahan telur yang cukup dapat meningkatkan kesukaan panelis pada mie kering karena kandungan protein pada telur memberikan aroma gurih pada mie kering. Namun panelis tidak menyukai mie kering dengan penambahan telur yang terlalu banyak karena membuat mie yang dihasilkan berbau amis, sehingga panelis lebih menyukai mie kering dengan penambahan telur $10 \%$.

\section{Kesukaan rasa}

Hasil uji hedonik (uji kesukaan) rasa mie kering dengan substitusi tepung sukun dan penambahan telur berkisar antara 2,97 - 4,37 (kurang suka sampai suka). Hasil sidik ragam rasa mie kering dengan taraf uji 5\% menunjukkan bahwa rasio tepung terigu dan tepung sukun dengan penambahan telur berpengaruh nyata terhadap kesukaan rasa panelis. 


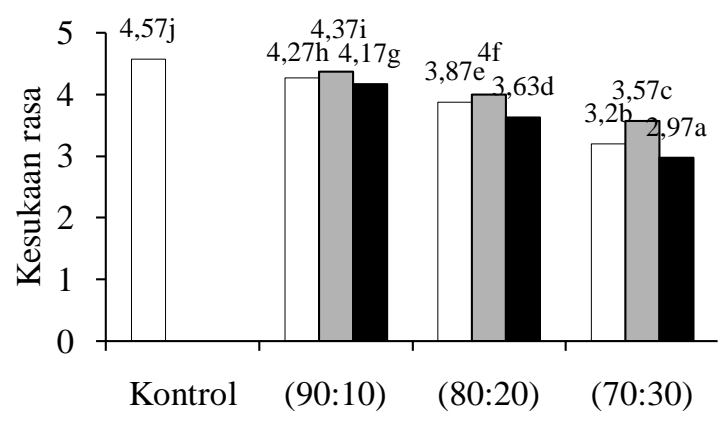

Rasio tepung terigu : tepung sukun

Gambar 7. Nilai kesukaan rasa mie kering dengan substitusi tepung sukun dan penambahan telur: $\square=5 \%, \square=10 \%$ dan $\mathbf{\square}=15 \%$

Nilai penerimaan panelis terhadap rasa mie kering semakin menurun seiring peningkatan konsentrasi substitusi tepung sukun karena tepung sukun pada mie yang dihasilkan memiliki rasa dan flavor yang khas yang jarang dirasakan oleh banyak panelis, sehingga panelis kurang menyukai mie dengan penggunaan tepung sukun yang semakin banyak. Karbohidrat pada tepung sukun terdiri dari sukrosa (415 $\mathrm{mg} / 100$ gram) yang memberikan karakteristik manis pada tepung sukun (Pratiwi, 2013). Penggunaan telur menimbulkan rasa yang gurih pada mie yang dihasilkan karena adanya lesitin pada kuning telur, namun panelis tidak menyukai penggunaan telur yang terlalu banyak karena membuat rasa mie yang dihasilkan terlalu anyir (amis).

\section{Kesukaan tekstur}

Hasil uji hedonik (uji kesukaan) tekstur mie kering dengan substitusi tepung sukun dan penambahan telur berkisar antara 3,07 - 4,2 (agak suka sampai suka). Hasil sidik ragam tekstur mie kering dengan taraf uji 5\% menunjukkan bahwa rasio tepung terigu dan tepung sukun dengan penambahan telur berpengaruh nyata terhadap kesukaan tekstur panelis.

Panelis menyukai mie dengan tekstur yang tidak mudah putus (elastis) dan sedikit kenyal. Tekstur mie semakin menurun seiring dengan meningkatnya komposisi tepung sukun. Hal ini dikarenakan tepung sukun tidak memiliki kandungan gluten. Gluten sangat berpengaruh pada pembentukan struktur mie. Dengan semakin rendahnya kandungan gluten dalam adonan, maka kemampuan adonan untuk mempunyai sifat elastis dan struktur yang kontinyu akan semakin rendah, sehingga mie yang dihasilkan mudah putus dan menurunkan penilaian panelis terhadap tekstur mie.

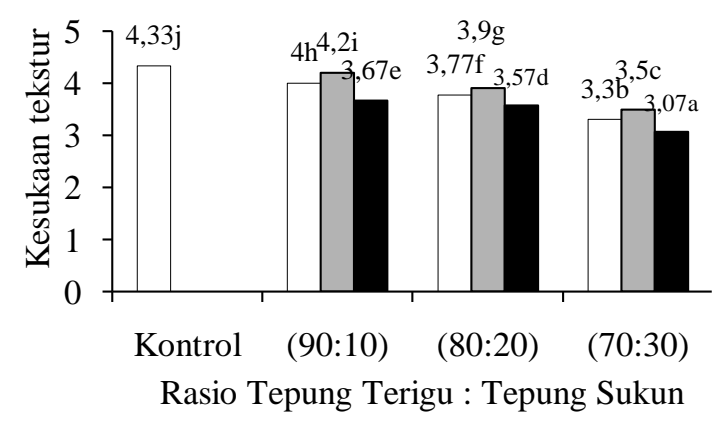

Gambar 8. Nilai kesukaan tekstur mie kering dengan substitusi tepung sukun dan penambahan telur : $\square 5 \%, \square 10 \%$, $\mathbf{\square}=15 \%$

Tekstur pada mie yang kurang baik juga dapat terjadi karena adanya proses retrogradasi pati antara amilosa yang terdispersi ke dalam air. Penggunaan telur mampu menurunkan amilosa terlarut, sehingga fraksi amilosa yang mengalami retrogradasi juga lebih sedikit. Hal ini menyebabkan tekstur mie menjadi lebih lunak karena pemberian telur berguna untuk meningkatkan kelembutan, elastis dan mengenyalkan mie.

Telur berfungsi sebagai bahan pengikat molekul pati yang terdapat pada tepung terigu dengan tepung sukun, sehingga dapat membantu pembentukan tekstur dari mie yang dihasilkan. Lesitin dalam kuning telur berfungsi sebagai pengemulsi, mempercepat hidrasi air pada tepung dan untuk mengembangkan adonan (Mulyadi et al., 2014). Putih telur dapat membentuk lapisan yang kuat atau daya rekat yang bagus, sehingga dapat memperbaiki tekstur mie. Namun, panelis 
tidak terlalu menyukai mie yang terlalu lembut (penambahan 15\% telur). Panelis cenderung lebih menyukai mie dengan penambahan telur sebanyak $10 \%$.

\section{Kesukaan keseluruhan}

Hasil uji hedonik kesukaan keseluruhan mie kering dengan substitusi tepung sukun dan penambahan telur berkisar antara 3,1 - 4,4 (agak suka sampai suka). Hasil sidik ragam kesukaan keseluruhan mie kering dengan taraf uji 5\% menunjukkan bahwa rasio tepung terigu dan tepung sukun dengan penambahan telur berpengaruh nyata terhadap kesukaan keseluruhan panelis.

Semakin meningkatnya konsentrasi substitusi tepung sukun dan penambahan telur menyebabkan menurunnya penilaian panelis terhadap kesukaan keseluruhan mie kering yang dihasilkan. Penilaian panelis terhadap kesukaan keseluruhan mie kering dipengaruhi oleh warna, aroma, rasa dan tekstur mie kering.

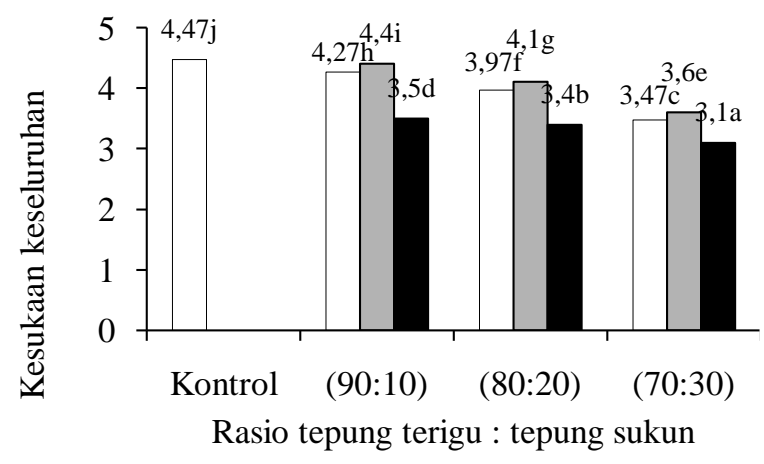

Gambar 9. Nilai kesukaan keseluruhan mie kering dengan substitusi tepung sukun dan penambahan telur : $\square=5 \%, \square=10 \%$ dan $\mathbf{v}=15 \%$

\section{Uji Efektivitas}

Uji efektivitas dilakukan untuk menentukan perlakuan terbaik dari semua perlakuan mie kering berdasarkan hasil uji sensoris yang dilakukan oleh beberapa panelis dan uji sifat fisik meliputi daya rehidrasi, cooking loss, warna dan elastisitas. Formulasi terbaik pada pembuatan mie kering yaitu pada perlakuan A1B2 (90\% tepung terigu: $10 \%$ tepung sukun dan penambahan telur 10\%). Perlakuan tersebut kemudian dilakukan pengujian kimia yang meliputi kadar protein, air, abu, lemak dan karbohidrat.

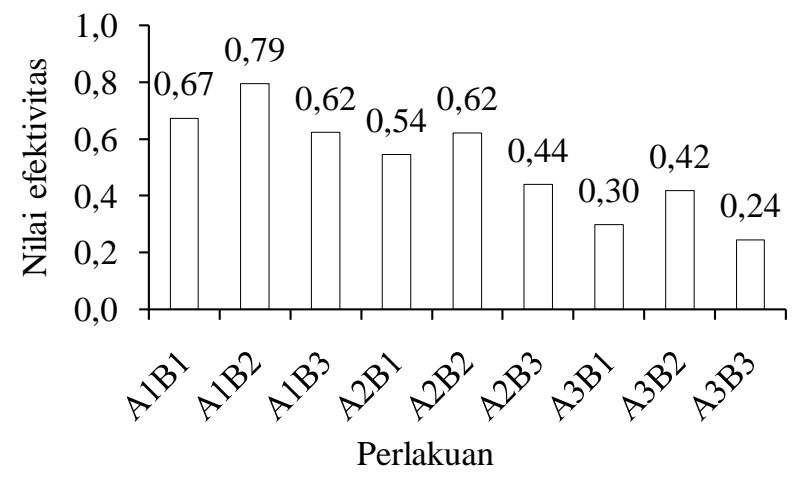

Gambar 10. Nilai efektivitas mie kering dengan substitusi tepung sukun dan penambahan telur

\section{Sifat Kimia}

\section{Kadar air}

Kadar air mie kering perlakuan terbaik berkisar antara 7,94-9,55\%. Hasil uji perbedaan rata-rata Independent T-Test dengan taraf uji 5\% diketahui bahwa substitusi tepung sukun dan penambahan telur berpengaruh tidak nyata terhadap kadar air mie kering.

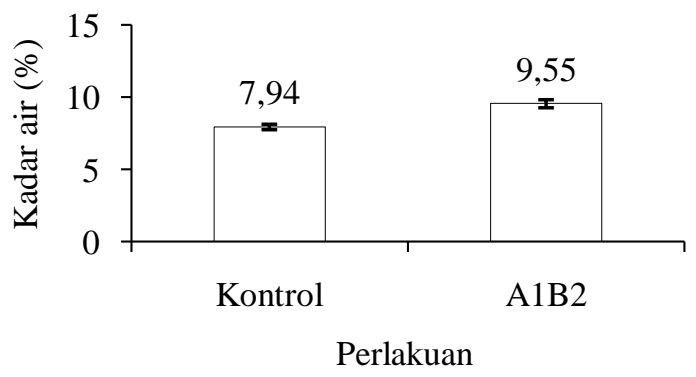

Gambar 11. Nilai kadar air mie kering perlakuan terbaik

Nilai kadar air mie kering yang disubstitusi dengan tepung sukun semakin tinggi karena tepung sukun tidak memiliki gluten. Kandungan gluten yang rendah dapat mengakibatkan daya ikat air semakin lemah, sehingga pelepasan molekul air pada saat pengeringan semakin mudah. Hal ini menyebabkan mie kering dengan konsentrasi substitusi tepung sukun 
memiliki kadar air yang lebih tinggi daripada mie kering kontrol.

Tepung sukun memiliki kadar air $(9,09 \%)$ (Widowati, 2003) yang lebih kecil dibandingkan dengan kandungan air tepung terigu protein tinggi (14\%). Namun, dengan adanya penambahan telur sebanyak 10\%, kadar air mie kering A1B2 hampir menyerupai mie kering control. Hal ini dikarenakan kandungan air pada telur ayam sebesar $\pm 73,7 \%$ (Komala, 2008).

Menurut SNI 01-2974-1996 tentang syarat mutu mie kering, kadar air mutu II maksimal sebanyak 10\% (wb), sedangkan kadar air mie kering A1B2 sebanyak 9,55\%. Dengan demikian, kadar air mie kering A1B2 memenuhi syarat mutu mie kering berdasarkan Standar Nasional Indonesia (SNI) mutu II.

\section{Kadar $a b u$}

Kadar abu mie kering perlakuan terbaik berkisar antara 0,24-0,58\%. Hasil uji perbedaan rata-rata Independent T-Test dengan taraf uji 5\% diketahui bahwa substitusi tepung sukun dan penambahan telur berpengaruh tidak nyata terhadap kadar abu mie kering.

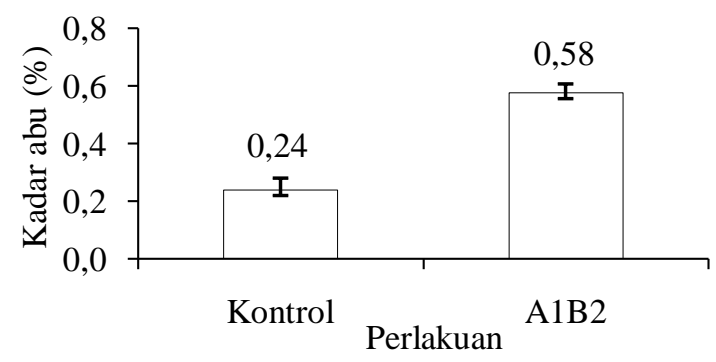

Gambar 12. Nilai kadar abu mie kering perlakuan terbaik

Nilai kadar abu mie kering yang disubstitusi dengan tepung sukun semakin tinggi. Tepung terigu memiliki kandungan abu yang lebih sedikit daripada tepung sukun, yakni pada tepung terigu sebesar 0,25-0,6\%, sedangkan pada tepung sukun sebesar 2,83\% (Widowati, 2003). Kandungan abu pada telur ayam sekitar 1 $\%$. Dengan demikian, kadar abu dari mie kering perlakuan terbaik lebih tinggi dibandingkan mie kontrol.

Kadar lemak

Kadar lemak mie kering perlakuan terbaik berkisar antara 1,12-2,21\%. Hasil uji perbedaan rata-rata Independent T-Test dengan taraf uji 5\% diketahui bahwa substitusi tepung sukun dan penambahan telur berpengaruh tidak nyata terhadap kadar lemak mie kering.

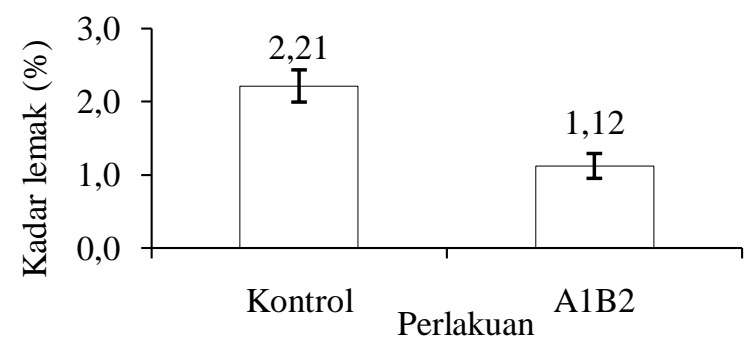

Gambar 13. Nilai kadar lemak mie kering perlakuan terbaik

Nilai kadar lemak mie kering yang disubstitusi dengan tepung sukun lebih rendah daripada mie kontrol karena kadar lemak tepung sukun lebih rendah daripada tepung terigu. Kadar lemak pada tepung sukun yang yaitu sebesar $0,8 \%$ (Direktorat Gizi Departemen Kesehatan RI, 2010) dan kadar lemak tepung terigu sebesar 1,3\% (Direktorat Gizi Departemen Kesehatan RI, 2010), sehingga dengan adanya substitusi tepung sukun, maka kadar lemak mie kering perlakuan yang dihasilkan semakin rendah. Kandungan lemak pada telur ayam sebesar 11,2\% (Komala, 2008). Dengan demikian, kadar lemak dari mie kering perlakuan terbaik lebih rendah dibandingkan mie kontrol.

\section{Kadar protein}

Kadar protein mie kering perlakuan terbaik berkisar antara 11,72-11,88\%. Hasil uji perbedaan rata-rata Independent T-Test dengan taraf uji 5\% diketahui bahwa substitusi tepung sukun dan penambahan telur berpengaruh tidak nyata terhadap kadar protein mie kering.

Adanya substitusi tepung sukun menyebabkan kadar protein dari mie 
kering menurun karena tepung sukun mempunyai kadar protein $(3,60 \%$ (Direktorat Gizi Departemen Kesehatan RI, 2010)) yang lebih kecil dibandingkan dengan kadar protein tepung terigu protein tinggi (12\%). Semakin berkurangnya kandungan protein gluten, kandungan protein mie kering semakin menurun. Namun, dengan adanya penambahan telur sebanyak $10 \%$, kadar protein mie kering A1B2 hampir menyerupai mie kering kontrol karena dalam setiap butir telur ayam utuh memiliki kandungan protein $\pm 12,9 \%$ (Komala, 2008).



Gambar 14. Nilai kadar protein mie kering perlakuan terbaik

Menurut SNI 01-2974-1996 tentang syarat mutu mie kering, kadar protein minimal mie kering adalah $11 \%$ untuk mutu I. Dengan demikian, kadar protein mie kering A1B2 telah memenuhi karakteristik syarat mutu mie kering berdasarkan Standar Nasional Indonesia (SNI) mutu I.

\section{Kadar karbohidrat}

Kadar karbohidrat mie kering perlakuan terbaik berkisar antara 77,04$77,73 \%$. Hasil uji perbedaan rata-rata Independent T-Test dengan taraf uji 5\% diketahui bahwa substitusi tepung sukun dan penambahan telur berpengaruh nyata terhadap kadar karbohidrat mie kering.

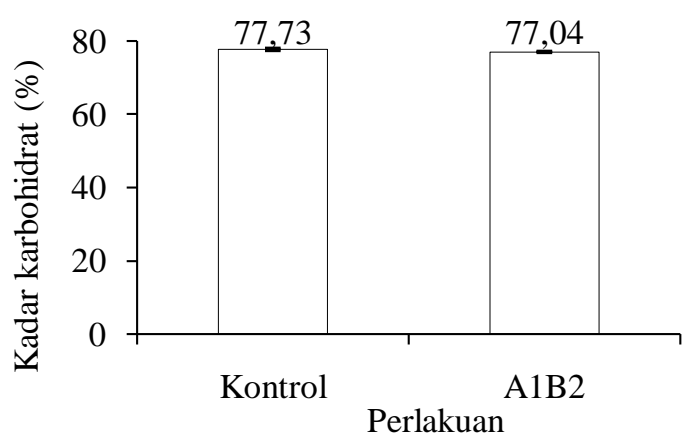

Gambar 15. Nilai kadar karbohidrat mie kering perlakuan terbaik

Kadar karbohidrat mie kering yang disubstitusi tepung sukun lebih rendah daripada mie kering kontrol karena kandungan karbohidrat tepung sukun lebih tinggi, yakni 78,9\% (Direktorat Gizi Departemen Kesehatan RI, 2010) dibandingkan dengan tepung terigu, yaitu sebesar 77,3\% (Direktorat Gizi Departemen Kesehatan RI, 2010). Semakin tinggi penambahan telur, kandungan karbohidratnya juga semakin meningkat. Hal ini dikarenakan telur dapat mengikat molekul pati yang terdapat pada tepung terigu dan tepung sukun, sehingga dapat meningkatkan stabilitas adonan mie kering. Kandungan karbohidrat pada telur ayam sebesar 0,9\% (Komala, 2008), sehingga tidak berdampak terlalu besar pada kandungan karbohidrat mie kering.

\section{KESIMPULAN}

Substitusi tepung terigu dan tepung sukun serta penambahan telur mempengaruhi daya rehidrasi, kesukaan warna, aroma, rasa, tekstur, kesukaan keseluruhan dan kadar karbohidrat, tetapi tidak mempengaruhi kecerahan warna, elastisitas, cooking loss, kadar air, kadar abu, kadar lemak dan kadar protein mie kering. Mie kering perlakuan terbaik berdasarkan uji efektivitas fisik dan sensoris yaitu mie kering A1B2 (90\% tepung terigu : $10 \%$ tepung sukun dan penambahan telur 10\%). Mie kering A1B2 mempunyai kadar protein $11,72 \%$; kadar air 9,55\%; kadar abu 0,58\%; kadar lemak 1,12\%; kadar karbohidrat $77,04 \%$; 
elastisitas 26,60 kg/s ; kecerahan warna 62,58; cooking loss $7,11 \%$; daya rehidrasi 151,36\%; kesukaan warna 4,03 (suka); kesukaan aroma 4,23 (suka); kesukaan rasa 4,37 (suka); kesukaan tekstur 4,2 (suka) dan kesukaan keseluruhan 4,4 (suka).

\section{DAFTAR PUSTAKA}

AACC. 2000. Approved Methods of The American Association of Cereal Chemists Methods 08-01, 46-30, 55-40, 66-50, 76-13 and 76e31, tenth ed. The Association, St Paul, MN.

Badan Standarisasi Nasional. 1996. SNI 012974-1996. Mi Kering. Badan Standarisasi Nasional, Jakarta.

Budijanto, S. 2009. Dukungan iptek bahan pangan pada pengembangan tepung lokal. Jurnal PANGAN, 54 (18).

Direktorat Gizi Kesehatan Republik Indonesia. 2010. Daftar Komposisi Bahan Makanan. Bhatara Karya Aksara, Jakarta.

FAO. 1972. FAO Year Book Forest Products. FAO, Roma.

Jannah, R., Sukatiningsih dan Diniyah Nurud. 2014. Formulasi tepung komposit dari terigu, kecambah jagung, dan rumput laut pada pembuatan mi kering. Jurnal Teknologi Pertanian, 15 (1): 15-24.

Khusna, C.L. 2016. "Karakterisasi Fisik dan Organoleptik Tepung Sukun dengan Variasi Jenis dan Konsentrasi Larutan Perendaman". Skripsi. Teknologi Hasil Pertanian, Universitas Jember, Jember.

Komala, I. 2008. Kandungan Gizi Produk Peternakan. Student Master Animal Science. Universiti Putra Malaysia, Malaysia.

Liu, L., Herald, T.J., Wang, D., Wilson, J.D., Bean, S.R. and Aramouni, F.M. 2012. Characterization of sorghum grain and evaluation of sorghum flour in a Chinese egg noodle system. Journal of Cereal Science. 55: 31-36.

Mulyadi, A.F., Wijana, S., Dewi, I.A., dan Putri, W.A. 2014. Karakteristik organoleptik produk mie kering ubi jalar kuning (Ipomoea batatas) (kajian penambahan telur dan CMC). Jurnal Teknologi Pertanian, 15 (1): 25-36.
Nurcahyo, E., Amanto, B.S., dan Nurhatadi. 2014. Kajian penggunaan tepung sukun (Artocarpus communis) sebagai substitusi tepung terigu pada pembuatan mie kering. Jurnal Teknosains Pangan, ISSN: 2302-0733, 3: 57-65.

Pratiwi, D.P. 2013. Pemanfaatan Tepung Sukun (Artocarpus altilis) pada Pembuatan Aneka Kudapan Sebagai Alternatif Makanan Bergizi Untuk Program PMT-AS. Institut Pertanian Bogor, Bogor.

Purwanita, R.S. 2013. "Eksperimen Pembuatan Egg Roll Tepung Sukun (Artocarpus altilis) dengan Penambahan Jumlah Tepung Tapioka yang Berbeda". Skripsi. Teknologi Jasa dan Produksi, Universitas Negeri Semarang, Semarang.

Puspanti, E. 2005. "Studi Pembuatan Mie Kering dengan Substitusi Tepung Sukun". Skripsi. Teknologi Hasil Pertanian, Universitas Jember, Jember.

Setianingrum dan Marsono, 1999. Pengkayaan Vitamin A dan Vitamin $E$ dalam pembuatan Mie Instan Menggunakan Minyak Sawit Merah. Kumpulan Penelitian Terbaik Bogasari 1998-2001. Bogasari, Jakarta.

Utami, I.S. 1992. Pengolahan Roti Pusat Antar Universitas Pangan dan Gizi. Universitas Gajah Mada, Yogyakarta.

Widowati, S. 2003. Prospek Tepung Sukun Untuk Berbagai Produk Makanan Olahan dalam Upaya Menunjang Diversifikasi Pangan. Institut Pertanian Bogor, Bogor.

Yousif, E.I., Gadallah, M.G.E. and Sorour, A.M. 2012. Physico-chemical and rheological properties of modified corn starches and its effects on noodle quality. Annals of Agricultural Science, 57 (1): 19-27.

Yuan, M-L., Lu, Z-H, Cheng, Y-Q. and Li, LT. 2008. Effects of spontaneous fermentation on the physical properties of corn starch and rheological characteristics of corn starch noodle. Journal of Food Engineering, 85: 12-17. 